\title{
Cytogenetic and Molecular Diagnosis of Fanconi Anemia
}

Diagnóstico citogenético e molecular da anemia de Fanconi

Carmen S. P. Lima ${ }^{1}$

Gustavo J. Lourenço

Davi E. A. Rodriguez ${ }^{2}$

Maristela Zocca ${ }^{1}$

Carmen S. Bertuzzo 2

${ }_{1}^{1}$ Haematology and Haemotherapy Centre.

2 Department of Medical Genetics, State University of

Campinas, Campinas, São Paulo, Brazil.

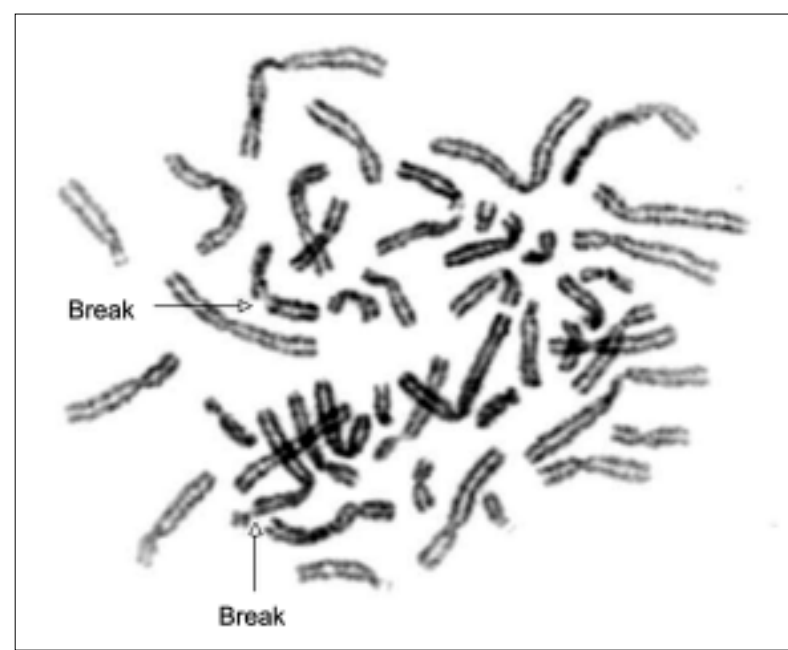

Fig. 1 - Chromosome spreads showing typical chromosome breaks (arrows) in the Fanconi anaemia patient analysed by the diepoxybutane test

Fanconi anaemia (FA) is an autosomal recessive disorder associated with a very high frequency of bone marrow failure, developmental abnormalities, such as aplasia of the thumb and radius, growth retardation,

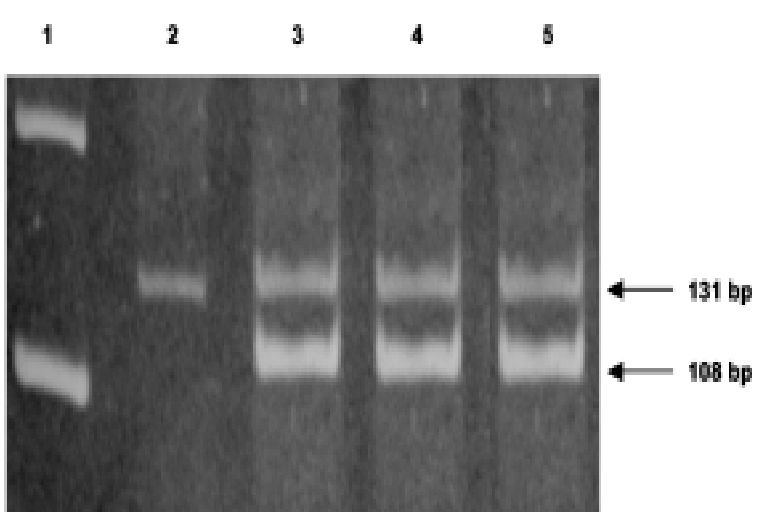

Fig. 2 - Polymerase chain reaction and restriction endonuclease digestion for detection of IVS4+4A? mutation of the FANCC gene. Ethidium bromide-stained $8 \%$ polyacrylamide gel showing fragments of $108 \mathrm{bp}$ corresponding to theabsence of the mutation and fragments of $131 \mathrm{bp}$ corresponding to the presence of the mutation. Lane 1 shows the DNA size markers Ladder 100 bp. Lane 2 shows the result from an individual with homozygous mutation (Fanconi anaemia) and lanes 3, 4 and 5 show the results from heterozygous individuals of the same family

hyper-pigmentation, kidney and urinary tract malformations, and high risk of developing a malignan disease, particularly acute myelogenous leukaemia. ${ }^{1}$

Somatic cell fusion studies have shown that FA is genetically heterogeneous, resulting from mutations in at least eight complementary gene groups (FANC A, B, C, D1, D2, E, F, and G). ${ }^{1}$

Lymphocytes culture shows an increased sensitivity to the clastogenic agents diepoxybutane (DEB) or mytomycin (MMC). These agents induce DNA damage, mutations, chromosomal rearrangements and cell death in FA patients. ${ }^{2}$ The DEB test is considered as the gold

Correspondence to: Carmen Silvia Passos Lima, MD, PhD.

Hemocentro - Unicamp - Cidade Universitária "Zeferino Vaz".

Caixa Postal 6198, Cep: 13083-970 - Campinas-SP - Brazil

Phone: + 5519 3788-8729 - Fax: + 5519 3788-8600 - E-mail: carmen|@unicamp.br 
standard for diagnosis of disease (reference). However, its effectiveness has been questioned considering that a negative test was found in some cases diagnosed by molecular analysis. ${ }^{3}$

Herein, we present one patient with aplastic anaemia, who was diagnosed as FA by conventional cytogenetic ${ }^{2}$ and molecular ${ }^{4}$ analyses (Figures 1 and 2). It is important to comment that both analyses permitted proper management of the haematologic disease and genetic counselling for the family.

\section{Bibliographic References}

1. Owen J. Fanconi Anemia: Standards for Clinical Care. Fanconi Anemia Research Foundation Incorporation, Oregon, USA. p. 106, 1999

2. Rosendorf J, Bernstein R, Macdougall L et al: Fanconi anemia: another disease of unusually high prevalence in the African population of South Africa. Am J Med Genet 1987;27:793-797.

3. Pearson T, Jansen S, Havenga $C$ et al: Fanconi anemia: a statistical evaluation of cytogenetic results obtained from South African families. Cancer Genet Cytogenet 2001;126:52-55

4. Gibson RA, Morgan NV, Goldstein LH et al: Novel mutations and polymorphisms in the Fanconi anemia group C gene. Human Mutat 1996;8:140-148.

Avaliação: Editor e um revisor externo

Conflito de interesse: não declarado

Recebido: 11/07/2003

Aceito após modificações: 15/08/2003 